\title{
Evaluation of Immunological Status of Calves Suffered from Diarrhea under Field Condition
}

\author{
Ashgan F. El-Sissi ${ }^{*}$; Abeer, S.Hafez ${ }^{1}$ and Atia, A. El-Gedawy ${ }^{2}$ \\ ${ }^{1}$ Department of Immunology, Animal Health Research Institute,Agricultural Research Center,Ministry of \\ Agriculture, Dokki, Cairo, Egypt. \\ ${ }^{2}$ Department of Bacteriology, Animal Health Research Institute,Agricultural Research Center,Ministry of \\ Agriculture, Dokki, Cairo, Egypt. \\ *Corresponding Author E-Mail: ashganfelsissi62@yahoo.com
}

\begin{abstract}
The objective of the present work was to evaluate some innate immune responses associated with neonatal calves' diarrhoea before and after treatment either with antibiotics or antibiotics plus fluid therapy. The experiment carried out on sixty diarrheic and 15 non-diarrheic healthy calves (from 15 up to 45 days of age). According to fever, the diarrheic calves divided into two main groups, febrile and non-febrile diarrheic calves. Then according to the type of receiving therapy, each main group is subdivided into two subgroups, receiving antibiotic or antibiotic plus Digeston ${ }^{\odot}$ for five days. The most common pathogens isolated from both groups of febrile diarrheic calves were E. coli (93.3\%) and Campylobacter spp. $(26.7 \%)$. The results showed that febrile diarrheic calves had a significant increase $(\mathrm{p}<0.05)$ in phagocytic activity; lysozyme; nitric oxide (NO); haptoglobin (HP); total protein (TP) and albumin as well as a significant decrease in immunoglobulin $\mathrm{G}$ (IgG) compared to control group. While in non-febrile diarrheic calves, there was a significant increase $(p<0.05)$ in HP; TP and albumin. By treatment, both therapies modulate the innate immune response to approach control value. It was clear that the antibiotic plus digeston ${ }^{\circledR}$ have much better results. It can be concluded that the lysozyme assay serves as a confirmatory test to differentiate between infectious and non-infectious diarrhoea of neonatal calves. Using IgG assay as a screening test may be essential to ensure that calves receive adequate colostrum early in life.
\end{abstract}

Keywords: Diarrhea, digeston ${ }^{\odot}$, fluid therapy, innate immunity, neonatal calves.
Original Article:

DOI: $\underline{\text { HTTPS://DX.DOI.ORG/10.2 }}$ $\underline{1608 / J A V S .2020 .85580}$

Received :21 Feb., 2020.

Accepted :21 March, 2020.

Published in April, 2020.

This is an open access article under the term of the Creative Commons Attribution $\quad 4.0 \quad$ (CC-BY) International License. To view a copy of this license, visit http://creativecommons.org/licenses/ by $/ 4.0 /$

J. Appl. Vet. Sci., 5(2 ): 40 - 48.

\section{INTRODUCTION}

Calf diarrhoea is one of the most serious problems in the livestock industry. Calf diarrhea considers the most important cause of economic losses arise from calf death, the cost of treatment as well as impaired calf growth and future performance (Smith, 2012).

Calf diarrhea is attributed to both infectious and non-infectious factors. Non-infectious diarrhoea includes environmental (e.g. improper animal hygiene), nutritional (e.g. excessive amounts of milk or milk replacer) (Kabu and Albayrak, 2016). The common agents of infectious calf diarrhoea include bacteria such as Escherichia coli and Salmonella spp., viruses such as rotavirus and coronavirus, and parasites as Toxocara vitulorum, Trichstrongylus spp., Eimeria spp. and Cryptosporidium spp. (Ramadan et al., 2015). Coinfection is frequently observed in diarrheic calves although a single primary pathogen can be the cause in some cases. The most common cause of neonatal diarrhea is Enterotoxigenic E. coli (ETEC). Which produces different virulence factors associating with colonization in the small intestine as the plasmidencoded K99 (Kaper et al., 2004). 
The physiology of the bovine placenta prevents the transfer of maternal serum immunoglobulin's to the calf before its born, therefore, calves are born a gamma globulinemic essentially and entirely dependent on Cloistral immunoglobulin at the first hours of life for protection from disease (Weaver et al., 2000). Inadequate colostrum consumption leads to failure of passive transfer (FPT), which is associated with increased morbidity and mortality before weaning (Dewell et al., 2006).

Acute-phase proteins (APPs) are a group of plasmatic proteins whose concentration increase after infection but are absent or present at low levels in healthy animals (Petersen et al., 2004). They are not suitable for establishing a specific diagnosis, but quantification of their concentration can provide objective information about the stage of clinical and subclinical infections also for the prognosis of their severity. Haptoglobin is one of the essential bovine APPs (Ganheim et al., 2007).

Treatment of neonatal calves' diarrhea is very similar, regardless of cause. All calves with diarrhea should receive proper nutritional support. Also, specific antimicrobial therapy should be established when infection confirmed or suspected. The main goal is to restore the health of the calf, not simply to adjust the volume and consistency of the feces (Smith, 2009). Therefore, the present study aimed to compare between two different treatment regimens (antibiotic only or antibiotic with Digeston ${ }^{(}$) through the determination of serum total protein, albumin, globulin, IgG, Hp, as well as some innate immune response as serum lysozyme, serum nitric oxide and phagocytic activity of peripheral blood mononuclear cells before and after treatment.

\section{MATERIALS AND METHODS}

\section{Digeston(C)}

Produced by Candles pharm Ismailia-Industry

Area K.E. Used in case of diarrhea and inflammation to regulate electrolyte and keep acid-base balance. Digeston $\odot$ contain Vit. A Vit. D3, Vit. E, Zn, Mn, Fe, $\mathrm{Cu}, \mathrm{I}, \mathrm{Se}$ and lactose as a carrier.

\section{2.. Animals and experimental design}

The present study was done using 15 healthy and 60 diarrheic newly born calves of both sexes from 15 up to 45 days of age that feed whole milk in a private farm in Sharkeia governorate. The diarrheic calves were selected at the early stage of the disease based on physical examination with special regard to body temperature and bacteriological examination. According to body temperature, the diarrheic calves were divided into two main groups (30 calves each), febrile diarrheic calves and non -febrile diarrheic calves then according to the type of receiving treatment each main group was subdivided into two subgroups (15 calves each) receiving antibiotics or antibiotics plus
Digeston(C) for five days according to manufacture instructions as following:

1-Group1 (G1): Control group $(n=15)$ were healthy calves.

2-Group2 (G2): Non-febrile diarrheic calves receiving antibiotic only.

3-Group3 (G3): Non-febrile diarrheic calves (receiving antibiotic plus digeston $\left.{ }^{\circledR}\right)$.

4-Group4 (G4): febrile infected diarrheic calves receiving antibiotic only.

5-Group5 (G5): febrile infected diarrheic calves receiving antibiotic plus digeston ${ }^{\circledR}$

\section{Sampling}

A total number of 75 rectal swabs were collected and transferred directly to the laboratory in a separate sterile plastic bag, under complete aseptic condition.Blood was collected from all groups at 0 times (before treatment), $3^{\text {rd }}$ and $5^{\text {th }}$ day post-treatment for serum separation to evaluate lysozyme, nitric oxide, total protein, albumin, IgG and haptoglobin. Also, heparinized blood was collected at the same time from all groups for phagocytosis assay.

\section{Bacteriological examination}

Isolation and identification of $E$. coli were done according to Koneman et al., (1992) and Quinn et al., (2013). Suspected colonies were subjected to further identifications, according to Edwards and Ewing, (1986).Cultivation and identification of Salmonella spp. where applied according to Morifnigo et al., (1986) and Chirino-Trejo (1999).The suspected colonies were identified serologically according to the Kauffman - white scheme by slide agglutination test. Isolation and identification of Campylobacter were done according to Klein et al., (2012). Each fecal sample was cultured onto 5\% sheep blood agar, then incubated at $37^{\circ} \mathrm{C}$ for $24 \mathrm{~h}$ and inspected for the presence of other bacterial pathogens.

5.Antibiotic sensitivity tests: The sensitivity test was done using standard diffusion method according to NCCLS (2002) and WHO (1977) (standards Table 1). The Oxoid discs including ten mcg ampicillin (AM), $30 \mathrm{mcg}$ cefotaxime (CTX), $30 \mathrm{mcg}$ tetracycline (TE), 25 mcg co-trimoxazol (SXT), five mcg ciprofloxacin )CIP), ten mcg gentamycin (GN), $30 \mathrm{mcg}$ cephalexin (CFX) and five mcg ofloxacin (OFF). Muller-Hinton medium was used. The percentage of sensitivity was calculated according to Fazlani et al., (2011).

\section{Treatment}

All diarrheic calves in the four groups received broad-spectrum antibiotics which proven to be antibiotic of choice by sensitivity test; ceftriaxone (20 $\mathrm{mg} / \mathrm{kg}$ body weight) or ciprofloxacin $(25 \mathrm{mg} / \mathrm{kg}$ body weight)). In addition to an antibiotic, the electrolytes $\left(\right.$ digeston $\left.^{\circledR}\right)$ were given to non-febrile diarrheic calves (G3) and febrile diarrheic calves (G5) up to $10 \%$ of body weight according to recommendations of producing company. 


\section{Evaluation of Immunological Status of Calves ......}

\section{Evaluation of the innate immune response}

7.1. Phagocytic activity: Phagocytic activity of peripheral blood mononuclear cell was determined using Candida albicans, according to Bos and Souza, (2000). The phagocytic percentage (number of phagocytic macrophages / total no of macrophages) and phagocytic index (number of macrophages engulf $\geq 3$ Candida spores / total no of macrophages) were calculated.

\subsection{Lysozyme Assay}

Lysozyme activity was measured by agarose gel plate lyses assay according to Peeters and Vantrappen 1977. The concentration of lysozyme obtained from the logarithmic curve of standard lysozyme.

\subsection{Nitric oxide assay}

It carried out according to Yang et al., (2010) by Griess reagent after deproteinization of serum, and reduction of nitrate to nitrite using copper-plated cadmium. The optical density was determined at 545 $\mathrm{nm}$ with an ELISA plate reader; the NO concentration was calculated from the standard curve using $\mathrm{NaNO} 2$.

\section{Estimation of serum protein profile:}

Serum total protein and albumin were estimated using commercial colorimetric diagnostic, kits obtained from biodiognostic.CAT.No.TP 2020 and AB 1010. Globulin concentration was evaluated by subtracting albumin from total protein.

\section{Determination of the immunoglobulin, $\mathrm{G}$ (IgG)}

Determination of levels of bovine serum IgG was done by Using Redial Immunodiffusion Binding site kits Ref (RN200.3) and Lot (338428).

\section{Evaluation of haptoglobin concentration}

Serum haptoglobin concentration was measured using commercial diagnostic kits (BENBiochemical enterprise S.r.l.-via Toselli, 4-20127 Milano -Italy. Ref HP3222.) following manufactures instructions.

\section{Statistical analysis}

The obtained data were statistically analyzed using one-way ANOVA test on a computer program SPSS-14 (2006).

\section{RESULTS}

The diarrheic calves appeared week, depressed with reduced appetite, fecal consistency was pasty and semi-liquid, dehydration was mild, and suckling reflex was moderate. The calves were monitored for 1-week post-treatment. During this period, all non -febrile diarrheic calves (30) which receive both treatments showed all signs of recovery within three days, and all febrile diarrheic calves that receive antibiotic + digeston $^{\circledR}$, (15calves) recovered within five days, while 13 out of 15 febrile diarrheic calves which receive antibiotic only showed all signs of recovery within seven days and two calves died. The two died calves were severely depressed.

\section{Bacteriological findings}

The prevalence of bacterial isolates (Table 1) showed that the most common pathogens isolated were E. coli followed by Proteus Vulgaris then Campylobacter and Salmonella species. Frequencies and distribution of E. coli (40 isolates) and 2 Salmonella serotypes were showed in Table (2). Results of antibiogram Table (3) revealed that (ciprofloxacin, cephalexin and ofloxacin) were the most effective antibiotics for treatment of diarrheic calves.

Table 1: Prevalence of bacterial isolates in the examined fecal samples.

\begin{tabular}{|ccccccc|}
\hline \multirow{2}{*}{$\begin{array}{c}\text { Bacterial } \\
\text { Species }\end{array}$} & \multicolumn{2}{c}{ Control } & \multicolumn{2}{c}{$\begin{array}{c}\text { febrile } \\
\text { diarrheic } \\
\text { calves }\end{array}$} & \multicolumn{2}{c|}{$\begin{array}{c}\text { Non-febrile } \\
\text { diarrheic } \\
\text { calves }\end{array}$} \\
\cline { 2 - 8 } & No. & $\%$ & No. & $\%$ & No. & $\%$ \\
\hline E. coli & $2 / 15$ & 13.3 & $28 / 30$ & 93.3 & $10 / / 30$ & 33.3 \\
\hline Campylobacter & $-\mathrm{ve}$ & $-\mathrm{ve}$ & $8 / 30$ & 26.7 & $-\mathrm{ve}$ & $-\mathrm{ve}$ \\
\hline $\begin{array}{c}\text { Salmonella } \\
\text { spp. }\end{array}$ & $-\mathrm{ve}$ & $-\mathrm{ve}$ & $6 / 30$ & 20 & $-\mathrm{ve}$ & $-\mathrm{ve}$ \\
\hline $\begin{array}{c}\text { Proteus } \\
\text { Vulgaris }\end{array}$ & $1 / 15$ & 6.6 & $20 / 30$ & 66.7 & $2 / 30$ & 6.6 \\
\hline
\end{tabular}

Table 2: Frequencies and distribution of E. coli serotypes and Salmonella serotypes recovered from examined fecal samples.

\begin{tabular}{|cccc|}
\hline E.coli & $\begin{array}{c}\text { Total no. } \\
\text { of isolates }\end{array}$ & $\begin{array}{c}\text { Salmonella } \\
\text { serotyping }\end{array}$ & $\begin{array}{c}\text { Total no } \\
\text { of isolates }\end{array}$ \\
\hline $\mathrm{O}_{157}$ & 12 & S. Typhimurium & 4 \\
\hline $\mathrm{O}_{119}$ & 4 & S. Enteritrdias & 2 \\
\hline $\mathrm{O}_{25}$ & 3 & -ve & -ve \\
\hline $\mathrm{O}_{111}$ & 8 & -ve & -ve \\
\hline $\mathrm{O}_{186}$ & 4 & -ve & -ve \\
\hline Untypable & 9 & -ve & -ve \\
\hline
\end{tabular}

Table 3: Sensitivity percentage of bacteria isolated from feces of all calves.

\begin{tabular}{|cccccccc|}
\hline $\begin{array}{c}\text { Bacterial } \\
\text { Species }\end{array}$ & $\begin{array}{c}\text { No.of } \\
\text { Isolates }\end{array}$ & Amm & Cfx & Cip & Ctx & Gn & Off \\
\hline E. coli & 40 & & 40 & 35 & 21 & 4 & 33 \\
\hline Salmonella & 6 & 1 & 5 & 6 & 3 & 2 & 4 \\
\hline Campylobacter & 8 & 5 & 8 & 8 & 6 & 8 & 8 \\
\hline $\begin{array}{c}\text { Proteus } \\
\text { vulgaris }\end{array}$ & 23 & 23 & 20 & 23 & 23 & 19 & 23 \\
\hline
\end{tabular}




\section{The phagocytic activity of peripheral blood mononuclear cells in calves}

The phagocytic percentage and index of peripheral blood mononuclear cells of both febrile diarrheic calves groups (G4 and G5) showed a significant increase. In contrast, non-febrile diarrheic calves groups don't show any change compared with the control group at zero time. The phagocytic index of non-febrile diarrheic calves treated by antibiotic plus digeston ${ }^{\circledR}$. (G3) showed a significant increase compared with that treated with antibiotic alone (G2) at $5^{\text {th }}$ day (Table 4 \& Figuer1).

Table 4: The phagocytic percentage and index of peripheral blood mononuclear cells of control and treated calves groups.

\begin{tabular}{|ccccccc|}
\hline \multirow{2}{*}{ Parameter } & \multirow{2}{*}{$\begin{array}{c}\text { Time post- } \\
\text { treatment }\end{array}$} & Control & \multicolumn{2}{c}{ Non -febrile diarrheic calves } & \multicolumn{2}{c|}{ Febrile diarrheic calves } \\
\cline { 3 - 7 } & & G1 & Antibiotic & Antibiotic+ & Antibiotic & Antibiotic+ \\
& & & G2 & digestion G3 & G4 & digestion G5 \\
\hline \multirow{2}{*}{$\begin{array}{c}\text { Phagocytic } \\
\text { Percentage }\end{array}$} & $3^{\text {rd }}$ day & $65.5 \pm 1.57$ & $60.33 \pm 0.67$ & $61.66 \pm 1.38$ & $63.16 \pm 2.38$ & $60.16 \pm 3.01$ \\
\cline { 2 - 7 } & $5^{\text {th }}$ day & $65.5 \pm 0.85^{\mathrm{a}}$ & $61 \pm 0.63^{\mathrm{ab}}$ & $68.33 \pm 1.14^{\mathrm{a}}$ & $57.16 \pm 2.62^{\mathrm{b}}$ & $63.16 \pm 3.45^{\mathrm{ab}}$ \\
\hline \multirow{2}{*}{$\begin{array}{c}\text { Phagocytic } \\
\text { Index }\end{array}$} & Zero time & $0.33 \pm 0.01^{\mathrm{b}}$ & $0.31 \pm 0.01^{\mathrm{b}}$ & $0.33 \pm 0.01^{\mathrm{b}}$ & $0.45 \pm 0.03^{\mathrm{a}}$ & $0.47 \pm 0.04^{\mathrm{a}}$ \\
\cline { 2 - 7 } & $3^{\text {rd }}$ day & $0.32 \pm 0.01$ & $0.29 \pm 0.01$ & $0.35 \pm 0.01$ & $0.28 \pm 0.02$ & $0.31 \pm 0.02$ \\
\cline { 2 - 7 } & $5^{\text {th }}$ day & $0.31 \pm 0.01^{\mathrm{ab}}$ & $0.28 \pm 0.02^{\mathrm{b}}$ & $0.34 \pm 0.01^{\mathrm{a}}$ & $0.27 \pm 0.01^{\mathrm{b}}$ & $0.31 \pm 0.01^{\mathrm{ab}}$ \\
\hline
\end{tabular}

Data were presented as the mean \pm standard error $(n=5)$. Mean with different superscript small litters indicated significantly different in the same row (between groups) $(\mathrm{P}<0.05)$

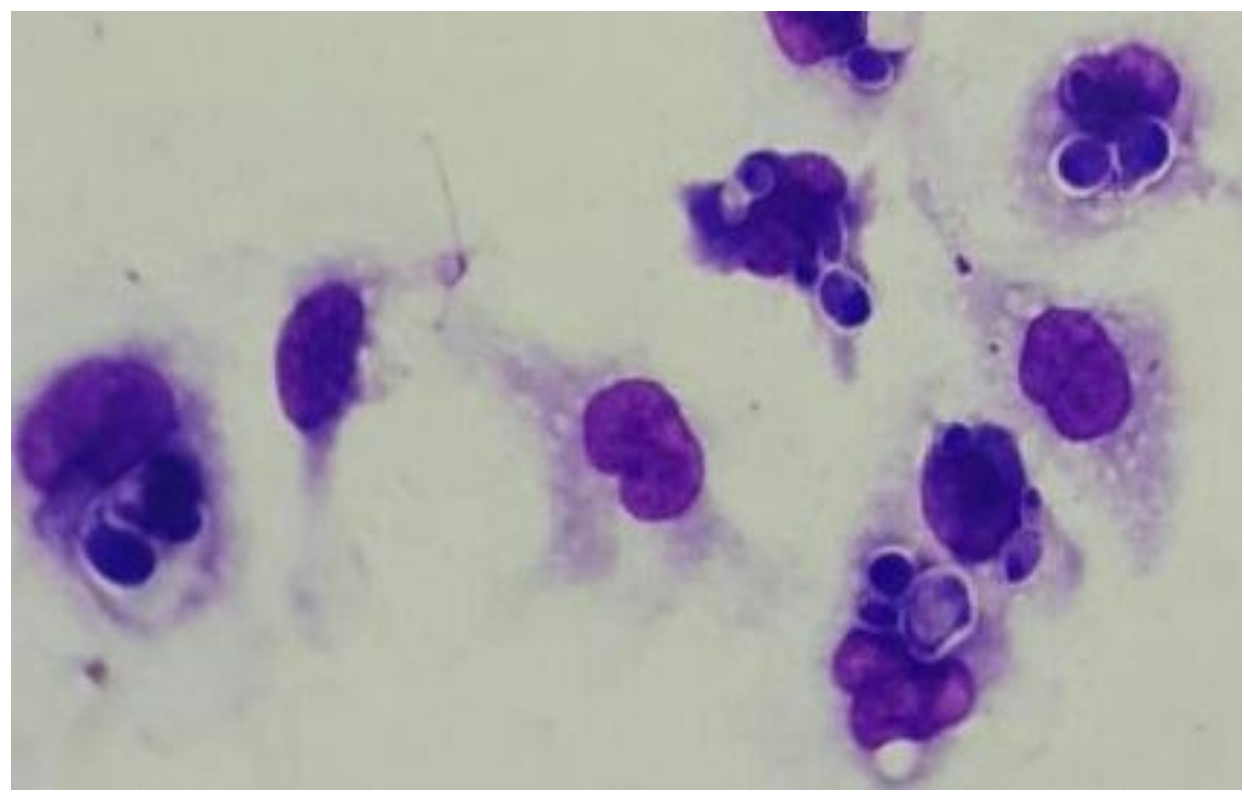

Figure 1: Peripheral blood mononuclear cells of febrile diarrheic calves engulfed Candida albicans spores $($ Giemsa stain $\times 100)$

\section{Serum lysozyme activity and nitric oxide values of calves}

Concerning to the results of lysozyme and NO (Table5), there was a significant increase in both of them in febrile diarrheic calves (G4 and G5) compared with non-febrile diarrheic calves (G2 and G3) and control group. By treatment, their values return to approach the control values at $5^{\text {th }}$ day in both treatments. While that of non-febrile diarrheic calves (G1and G2), don't show any significant change in both parameters. 
Evaluation of Immunological Status of Calves

Table 5: Lysozyme and Nitric oxide level of control and treated calves groups.

\begin{tabular}{|c|c|c|c|c|c|c|}
\hline \multirow[b]{2}{*}{ Parameter } & \multirow{2}{*}{$\begin{array}{l}\text { Time post- } \\
\text { treatment }\end{array}$} & \multirow[b]{2}{*}{$\begin{array}{l}\text { Control } \\
\text { G1 }\end{array}$} & \multicolumn{2}{|c|}{ Non-febrile diarrheic calves } & \multicolumn{2}{|c|}{ Febrile diarrheic calves } \\
\hline & & & $\begin{array}{l}\text { Antibiotic } \\
\text { G2 }\end{array}$ & $\begin{array}{l}\text { Antibiotic + } \\
\text { digeston G3 }\end{array}$ & $\begin{array}{l}\text { Antibiotic } \\
\text { G4 }\end{array}$ & $\begin{array}{l}\text { Antibiotic } \\
\text { +digeston (G5) }\end{array}$ \\
\hline \multirow{3}{*}{$\begin{array}{l}\text { Lysozyme } \\
(\mu \mathrm{g} / \mathrm{ml})\end{array}$} & Zero time & $10.59 \pm 0.67 \mathrm{~b}$ & $9.81 \pm 0.59^{b}$ & $9.67 \pm 0.34^{b}$ & $174.2 \pm 4.9^{\mathrm{a}}$ & $180.13 \pm 6.15^{\mathrm{a}}$ \\
\hline & $3^{\text {rd }}$ day & $9.82 \pm 0.56^{b}$ & $10.94 \pm 1.23^{b}$ & $11.75 \pm 0.39^{b}$ & $75.9 \pm 4.5^{\mathrm{a}}$ & $69.94 \pm 5.4^{\mathrm{a}}$ \\
\hline & $5^{\text {th }}$ day & $11.54 \pm 0.6$ & $9.62 \pm 1.05$ & $12.94 \pm 0.15$ & $12.23 \pm 1.26$ & $13.25 \pm 2.84$ \\
\hline Nitric & Zero time & $6.19 \pm 0.41^{b}$ & $5.64 \pm 0.31^{b}$ & $6.67 \pm 0.34^{b}$ & $16.23 \pm 0.75^{\mathrm{a}}$ & $17.47 \pm 0.91^{\mathrm{a}}$ \\
\hline Oxide & $3^{\text {rd }}$ day & $6.59 \pm 0.34^{b}$ & $6.23 \pm 0.24^{b}$ & $6.75 \pm 0.39^{b}$ & $14.47 \pm 0.72^{\mathrm{a}}$ & $8.42 \pm 0.57$ \\
\hline$(\mu \mathrm{mol} / \mathrm{ml})$ & $5^{\text {th }}$ day & $7.45 \pm 0.13$ & $5.88 \pm 0.75$ & $5.94 \pm 0.15$ & $9.37 \pm 0.34$ & $7.15 \pm 0.57$ \\
\hline
\end{tabular}

Data were presented as the mean \pm standard error $(n=15)$. Mean with different superscript small litters indicated significantly different in the same row (between groups) $(\mathrm{P}<0,05)$.

\section{Serum total protein profile of calves}

Serum TP concentration was statistically higher in all diarrheic calves febrile and non-febrile (G2, G3, G4 and G5) compared with the control group that contributed to a significant increase in albumin. Concerning the globulin values, febrile diarrheic calves ( $\mathrm{G} 4$ and G5) revealed a significant decrease in globulin values in comparison with the control group (G1) and non-febrile diarrheic calves which lead to a significant increase in A/G ratio. The TP profile was greatly corrected in groups treated by dehydrated therepy+ antibiotic than that treated with antibiotic alone (Table 6).

Table 6: Serum protein profile in control and treated calves groups

\begin{tabular}{|c|c|c|c|c|c|c|}
\hline \multirow{2}{*}{ Parameter } & \multirow{2}{*}{$\begin{array}{l}\text { Time post- } \\
\text { treatment }\end{array}$} & \multirow[b]{2}{*}{$\begin{array}{l}\text { Control } \\
\text { G1 }\end{array}$} & \multicolumn{2}{|c|}{ Non -febrile diarrheic calves } & \multicolumn{2}{|c|}{ Febrile diarrheic calves } \\
\hline & & & $\begin{array}{l}\text { Antibiotic } \\
\text { (G2) }\end{array}$ & $\begin{array}{l}\text { Antibiotic+ } \\
\text { digeston(G3) }\end{array}$ & $\begin{array}{l}\text { Antibiotic } \\
\text { (G4) }\end{array}$ & $\begin{array}{l}\text { Antibiotic+ } \\
\text { digeston (G5) }\end{array}$ \\
\hline \multirow{3}{*}{$\begin{array}{l}\text { Total } \\
\text { protein } \\
(\mathrm{gm} . / \mathrm{dl})_{-}\end{array}$} & Zero time & $5.56 \pm .36^{\mathrm{b}}$ & $6.73 \pm .71^{\mathrm{a}}$ & $6.91 \pm 30^{\mathrm{a}}$ & $6.60 \pm .27^{\mathrm{a}}$ & $6.55 \pm .20^{\mathrm{a}}$ \\
\hline & $3^{\text {rd }}$ day & $5.65 \pm .18$ & $5.99 \pm .21$ & $5.91 \pm .22$ & $6.17 \pm .25$ & $6.07 \pm, 39$ \\
\hline & $5^{\text {th }}$ day & $5.68 \pm .31$ & $5.55 \pm .23$ & $5.02 \pm .22$ & $5.86 \pm 26$ & $5.69 \pm .23$ \\
\hline \multirow{3}{*}{$\begin{array}{l}\text { Albumin } \\
(\mathrm{gm} . / \mathrm{dl})\end{array}$} & Zero time & $2.62 \pm .12^{\mathrm{b}}$ & $3.15 \pm .11^{b}$ & $3.25 \pm .13^{\mathrm{ab}}$ & $3.91 \pm .13^{\mathrm{a}}$ & $3.96 \pm .16^{\mathrm{a}}$ \\
\hline & $3^{\text {rd }}$ day & $2.54 \pm .09^{b}$ & $2.96 \pm .19^{\mathrm{ab}}$ & $3.15 \pm .23^{\mathrm{ab}}$ & $3.17 \pm .31^{\mathrm{a}}$ & $3.44 \pm .29^{\mathrm{a}}$ \\
\hline & $5^{\text {th }}$ day & $2 . .64 \pm .15^{\mathrm{ab}}$ & $2.78 \pm .18^{\mathrm{ab}}$ & $2.45 \pm .16^{\mathrm{b}}$ & $3.11 \pm 0.19^{\mathrm{a}}$ & $2.89 \pm .14^{\mathrm{ab}}$ \\
\hline \multirow{3}{*}{$\begin{array}{l}\text { Globulin } \\
(\mathrm{gm} . / \mathrm{dl})\end{array}$} & Zero time & $2.94 \pm .24^{\mathrm{ab}}$ & $3.58 \pm .2^{\mathrm{ab}}$ & $3.65 \pm .18^{\mathrm{a}}$ & $2.69 \pm .21^{\mathrm{b}}$ & $2.59 \pm .2^{\mathrm{b}}$ \\
\hline & $3^{\text {rd }}$ day & $3.11 \pm .13$ & $3.02 \pm .21$ & $2.81 \pm .23$ & $3.00 \pm .50$ & $2,63 \pm .18$ \\
\hline & $5^{\text {th }}$ day & $2.93 \pm .19$ & $2.77 \pm .24$ & $2.57 \pm .12$ & $2.75 \pm .23$ & $2.81 \pm .21$ \\
\hline \multirow{3}{*}{$\begin{array}{l}\mathrm{A} / \mathrm{G} \\
\text { ratio }\end{array}$} & Zero time & $.9 \pm .13^{\mathrm{b}}$ & $.89 \pm .05^{\mathrm{b}}$ & $0.89 \pm .09^{\mathrm{b}}$ & $1.46 \pm .15^{\mathrm{a}}$ & $1.52 \pm .19^{\mathrm{a}}$ \\
\hline & $3^{\text {rd }}$ day & $.83 \pm .04$ & $.98 \pm 0.03$ & $1.10 \pm .17$ & $1.06 \pm .37$ & $1.30 \pm .23$ \\
\hline & $5^{\text {th }}$ day & $.92 \pm .05$ & $1.04 \pm .17$ & $.96 \pm .07$ & $1.14 \pm .11$ & $1.03 \pm .12$ \\
\hline
\end{tabular}

Data were presented as the mean \pm standard error $(n=15)$. Mean with different superscript small litters indicated significantly different in the same row (between groups) $)(\mathrm{P}<0,05)$.

Serum immunoglobulin $\mathbf{G}$ of calves 
The serum (IgG) concentration of febrile diarrheic calves (G4 and G5) revealed a significant decrease in IgG level in comparison with the control group (G1). In contrast, non-febrile diarrheic calves (G 2 and G3) were fluctuated below and above the control group. No effect of both treatments on serum IgG calves in all treated groups (Table 7).

\section{Serum haptoglobin values of calves}

Haptoglobin levels were statistically higher in all diarrheic calves febrile and non-febrile (G2, G3, G4 and G5) when compared with the control group (Table 7). However, it was observed that the mean concentrations of Hp were higher in febrile than non-febrile diarrheic calves. By treatment, Hp levels decrease to approach control values in all groups.

Table 7: Serum Immunoglobulin-G (IgG ) levels and Haptoglobin (Hp) of control and treated calves groups.

\begin{tabular}{|ccccccc|}
\hline \multirow{2}{*}{ Parameter } & \multirow{2}{*}{$\begin{array}{c}\text { Time post- } \\
\text { treatment }\end{array}$} & Control & Antibiotic G2 & $\begin{array}{c}\text { Antibiotic+ } \\
\text { Digeston G 3 }\end{array}$ & Antibiotic G4 & $\begin{array}{c}\text { Antibiotic+ } \\
\text { digestonG5 }\end{array}$ \\
\cline { 3 - 6 } & Zero time & $40.25 \pm 1.28^{\mathrm{a}}$ & $39.51 \pm 1.18^{\mathrm{a}}$ & $42.75 \pm 1.95^{\mathrm{a}}$ & $24.83 \pm 0.96^{\mathrm{b}}$ & $25.01 \pm 1.58^{\mathrm{b}}$ \\
\cline { 2 - 6 } $\begin{array}{c}\mathrm{IgG} \\
(\mathrm{mg} / \mathrm{L})\end{array}$ & $3^{\text {rd }}$ day & $42.75 \pm 1.34^{\mathrm{a}}$ & $41.28 \pm 0.75^{\mathrm{a}}$ & $41.66 \pm 1.18^{\mathrm{a}}$ & $26.77 \pm 1.02^{\mathrm{b}}$ & $28.5 \pm 1.25^{\mathrm{b}}$ \\
\cline { 2 - 6 } & $5^{\text {th }}$ day & $39.5 \pm 0.81^{\mathrm{a}}$ & $40.75 \pm 1.97^{\mathrm{a}}$ & $41.33 \pm 1.59^{\mathrm{a}}$ & $29.89 \pm 2.01^{\mathrm{b}}$ & $28.24 \pm 0.64^{\mathrm{b}}$ \\
\hline \multirow{3}{*}{$\begin{array}{c}\mathrm{Hp} \\
(\mathrm{mg} / \mathrm{dl})\end{array}$} & Zero time & $3.38 \pm 0.61^{\mathrm{c}}$ & $7.68 \pm 0.71^{\mathrm{b}}$ & $8.74 \pm 0.63^{\mathrm{b}}$ & $18.1 \pm 2.18^{\mathrm{a}}$ & $18.5 \pm 2.47^{\mathrm{a}}$ \\
\cline { 2 - 6 } & $3^{\text {rd }}$ day & $3.42 \pm 0.34^{\mathrm{b}}$ & $5.08 \pm 0.84^{\mathrm{b}}$ & $6.12 \pm 0.32^{\mathrm{b}}$ & $11.52 \pm 0.64^{\mathrm{a}}$ & $9.84 \pm 0.55^{\mathrm{a}}$ \\
\cline { 2 - 6 } & $5^{\text {th }}$ day & $3.6 \pm 0.46$ & $4.2 \pm 0.27$ & $3.28 \pm 0.19$ & $7.72 \pm 0.5$ & $4.12 \pm 0.55$ \\
\hline
\end{tabular}

Data are presented as the mean \pm standard error $(n=15)$. Mean with different superscript small litters indicate significantly different in the same row (between groups) $)(\mathrm{P}<0,05)$.

\section{DISCUSSION}

Despite significant progress in understanding the pathophysiology of neonatal diarrhea, it considers one of the most significant causes of economic loss for the cattle industry.Bacteriological examination of fecal samples in the present study revealed that the most common pathogens isolated were E. coli at $93.3 \%$ in febrile diarrheic calves and $33 \%$ in non-febrile diarrheic calves followed by Proteus vulgaris at $66.67 \%$ in febrile diarrheic calves and $6.67 \%$ in nonfebrile diarrheic calves. Salmonella species and Campylobacter spp. were isolated only from febrile diarrheic calves at an incidence of (20 and 26.67\%) respectively. In the similar study Elhamy, et al., (2012) stated that the total bacteria isolated from fecal samples were E. coli, $S$. Typhimurium and Campylobacter spp.

The nearly similar rates of incidence to our results, E. coli was recovered from diarrheic calves by Kirkan et al., (2018) at the rate of (94\%) and Badawy (2015) at a rate of $(92.75 \%)$ and higher than that reported by Mohammed $\boldsymbol{e t}$ al. (2019), who recovered $E$. coli at a rate of $(46.4 \%)$. This high and low incidence of $E$. coli may be due to the difference in the study area, age of calves, farm size, managements, and hygiene measurements (Mohammed et al., 2019).

In the present study, serological identification of E. coli (40 isolates), revealed that the $E$. coli were typed as
O157 (12), O119 (4), O25 (3), O111 (8), O186 (4), and untypable E. coli (9). These findings were similar to results of Elhamy et al., (2012) who stated that the most common E. coli serotypes isolated from diarrheic fecal samples were as K99, O157, O111, O125, O119, $\mathrm{O} 26$ and O128. Bacteriological examination revealed that 6 out of 30 fecal samples (20\%) were positive for Salmonella spp. Two Salmonella serovars were elucidated, namely, S. Typhimurium (13.33\%) and $S$. Enteritidis (6.67\%). In a similar study, Abdullah et al., (2013) recorded that $25 / 114(21.9 \%)$ samples were positive for Salmonella spp.

Antibiotics should be used against E. coli and Salmonella infection after doing sensitivity test to choose the best drug, as inappropriate use of antibiotics can lead to serious antibiotic resistance problems (Muktar et al., 2015). Results of antibiogram revealed that (ciprofloxacin, cephalexin and ofloxacin) were the most effective antibiotics for treatment of diarrheic calves. Most isolated bacteria showed different degrees of resistance to ampicillin, cefotaxime and gentamycin. Elhamy et al., (2012) mentioned that the in vitro sensitivity of recovered isolates of $E$. coli from diarrheic fecal samples to different antimicrobial agents were highly sensitive for most of them.

Regarding the phagocytic activity of peripheral blood mononuclear cells, there was a significant increase in both groups of febrile diarrheic calves (G4 and G5). This may be due to the acute infectious 


\section{Evaluation of Immunological Status of Calves}

gastroenteritis that is characterized by an increase in the mucosal macrophage population. Macrophages use their pattern recognition receptors to recognize the molecular patterns associated with pathogens leading to its activation and secretion of pro-inflammatory cytokines that are important in the inflammatory responses (Tripathi et al., 2007). Both therapies modulate the phagocytic activity to approach control value at $3^{\text {rd }}$ day. Also, it was clear that Digeston ${ }^{\circledR}$ exhibited positive effects on the phagocytic index of calves in G3 \& G5 compared with that treated with antibiotic alone $\left(\mathrm{G} 2\right.$ \& G4) as Digeston ${ }^{\circledR}$ contains multivitamins (vitamin A, E and D3) and micronutrient such as (iron, manganese, copper, iodine and zinc) which enhances the immune function (El-Gamal $\boldsymbol{e t}$ al., 2011). Also, zinc supplementation may be beneficial in boosting immune responses (Gammoh and Rink, 2017).

Regarding lysozyme (non-antibody factor), the significant increase in lysozyme in febrile diarrheic groups (G4 and G5) may be attributed to activation of the phagocytic cell against bacterial infection. Lysozyme may play an essential role in immunity not only by augmenting antibody action but also by offering protection before the immune response becomes active, thus bridging the Immunological gap. These results supported by the results of Tew $\boldsymbol{e t}$ al., (1971), who recorded that, a single I/V injection of endotoxin (product of gram-negative bacteria) into rabbits resulted in a 4- to 5-fold increase in plasma lysozyme.

Nitric oxide is an important cytotoxic molecule used by macrophage in the defence against various infectious agents (Luiking et al., 2005). In the present study, there is a significant increase in NO in febrile diarrheic groups (G4 and G5) in comparison with both control and non-febrile diarrheic groups. It was recorded that NO concentration was significantly higher in calves with acute diarrhea (Kojouri et al., 2012; Gultekin et al., 2019). It was suggested that acute infectious gastroenteritis characterizes by inflamed mucosa with an increasing number of activated macrophages that responsible for the release of cytokines and inflammatory mediators. These mediators are known to induce the production of NO by phagocytic leukocytes (Rachmilewitz et al., 1995). It was known that a large amount of NO is produced over a long period during the inflammatory process of infectious disease (Sowmyanarayanan et al., 2009). Additionally, diarrheic calves had decreased renal perfusion related to hypovolemic. Decreased urinary excretion of nitrate might contribute to increased plasma NO concentration of the diarrheic calves (Gultekin et al., 2019).

In the present study, the significant increase of total serum protein and serum albumin were observed in all diarrheic calves' groups when compared with that of control calves. Our findings were in agreement with (Seifi et al., 2006; Guzelbektes et al., 2007; Badawy 2015). The increase in TP and albumen may result from the decrease in extracellular fluid volume and hemoconcentration caused by diarrhea (Niaze et al., 2000). The non-significant decrease in serum globulin concentration in febrile diarrheic groups (G4 \& G5) may be due to failure of passive transfer (FPT) of immunoglobulin (Ghanem et al., 2012). Moreover, the TP profile was significantly corrected in groups treated by fluid therapy (Digeston $\odot$ ) + antibiotic than that treated with antibiotic alone as the dehydration was corrected by oral fluid Therapy.

Regarding serum IgG concentrations, the significant decrease was recorded in the febrile diarrheic groups (G4 \& G5) in comparison with that of non-febrile groups (G2 \& G3) and the control group. The current results were in agreement with the finding of some recent studies (Berge et al., 2009; Balikci and AL, 2014; Al-Alo et al., 2018) who recorded that the levels of $\mathrm{IgG}$ in diarrheic calves were significantly decreased than that of healthy calves. It is not clear whether the decrease of IgG is the cause or the result of calf's diarrhea. Nunn et al., (1993) suggested that the decrease in IgG concentrations in calves with scours may indicate the use of immunoglobulin to combat infection. Other studies had shown that calves with lower serum IgG concentrations faced an increased chance of diarrhea (Dratwa-Chalupnik et al., 2012; Al-Alo et al., 2018).

In the present study, Hp levels (one of the major acute-phase proteins in the bovine) were statistically higher in all diarrheic calves in comparison with the control group. However, the mean concentrations of $\mathrm{Hp}$ were higher in febrile than non-febrile diarrheic calve. The increase in $\mathrm{Hp}$ concentration may be attributed to an infectious factor which activates macrophage to secrete pro-inflammatory cytokines, which initiate synthesis of acutephase proteins from the liver cells (Tripathi $\boldsymbol{e t}$ al., 2007; Kabu and Albayrak, 2016). Our findings agree with (Pourjafar et al., 2011; Balikci, and Al, 2014) who reported that the Hp correlated with fecal scores and proved to be reliable indicators of the severity of diarrhea. It was recorded that diarrheic calves with fever had a significant increase in their $\mathrm{Hp} \quad(\mathrm{P}<0.001)$ compared to diarrheic calves without fever (Hajimohammadi et al., 2013; Murray et al., 2014).

\section{CONCLUSION}

It can be concluded that, providing diarrheic neonatal calves with sufficient oral rehydration therapy consider the top priority for treatment. 
Then after detection of the causative agent, antibiotics were provided. The measurement of serum lysozyme on $1^{\text {st }}$ day of diarrhea is a simple, rapid inexpensive test that could serve as a confirmatory test to differentiate between infectious and non-infectious diarrhea. Moreover, the decrease of IgG concentration in calves with diarrhea suggests that special care must be given to neonatal calves to make sure that they receive adequate colostrum early in life soon after parturition up to $12 \mathrm{hrs}$. It can be recommended that additional studies are required to define the optimal cutoff of the concentration of lysozyme in infectious and non-infectious diarrhea. Also, further investigations are needed for studying drugs resistance gene for every infectious cause for definite therapy, where the absence gene expression give signals for the successful function of treatments.

\section{REFERENCES}

ABDULLAH, M., AKTER, M.R., LUTFUL KABIR, S. M., ABU SAYED KHAN, M., AND IBNE ABDUL AZIZ, M.Z.. 2013. Characterization of Bacterial Pathogens Isolated from Calf Diarrhea in Panchagarh District of Bangladesh .J. Agric. Food. Tech., 3(6)813 ,

AL-ALO, K. Z. K., NIKBAKHTBRUJENI, G.H., LOTFOLLAHZADEH , S., MOOSAKHANI, F., AND GHARABAGHI, A., 2018. Passive protective effect of anti-K99 antibodies against enterotoxigenic E.coli infection in neonatal calves. Iran J Vet Med., Vol. 12, No 2 19(1):3-8.

BADAWY, A.M., 2015. Microbial and immunological parameters relationship in diarrheic calves. $\mathrm{PhD}$ Thesis, Dept. of Microbiology, Fac. Vet Med., Alexandria University

BALIKCI, E. AND AL, M., 2014. Serum acute phase proteins and immunoglobulins concentrations in calves with rotavirus, coronavirus, E. coli F5 and Eimeria species. Iranian J.of Veterinary Research, Shiraz University, Vol. 15, No. 4, Ser. 49:397-401.

BERGE, A. C., BESSER, T. E., MOORE, D. A., AND SISCHO, W. M., 2009. Evaluation of the effects of oral colostrum supplementation during the first fourteen days on the health and performance of preweaned calves. J. Dairy. Sci., 92:286-295.

BOS, H., AND DE SOUZA, W., 2000. Phagocytosis of yeast: a method for concurrent quantification of binding and internalization using differential interference contrast microscopy. Journal of Immunological Methods, 238:29-43.

CHIRINO-TREJO, J.M., 1999. A more sensitive procedure for the detection of Salmonella carriers in swine. Proc. Western Canadian Assoc. Swine Pract. : 50-53.

DEWELL, R.D., HUNGERFORD, L.L., KEEN, J.E., LAEGREID W.W., GRIFFIN, D.D., RUPP, G.P., AND GROTELUESCHEN, D.M., 2006. Association of neonatal serum immunoglobulin G1 concentration with health and performance in beef calves. J Am Vet Med Assoc.15;228 (6):914-21

DRATWA-CHAUPNIK, A., HEROSIMCZYK, A., LEPCZYÑSKI, A., AND SKRZYPCZAK, W. F., 2012. Calves with diarrhea and a water-electrolyte balance. Medycyna Wet. , 68 (1):5-8

EDWARDS, P.R., AND EWING, W.H., 1986. Identification of Enterobacteriaceae. 4th edition. Published by Elsevier in New York.

EL-GAMAL, Y.M., ELMASRY, O.A., ELGHONEIMY, D.H., AND SOLIMAN, I. M., 2011. Immunomodulatory effects of food. Egypt J Pediatr Allergy Immunol 9(1):3-13.

Elhamy, I.A., Eman, M.S., and Eman, M.Z.,2012. Bacterial diarrhea in newly born calves in Menoufiea Governorate.Assiut Vet. Med. J.58:126-137.

FAZLANI, S.A., KHAN, S.A.,FARAZ1, S., AND AWAN, M.S.,2011. Antimicrobial susceptibility of bacterial species identified from mastitic milk samples of the camel. J African of Biotech; 10 (15), 2959-2964.

GAMMOH, N.Z., AND RINK, L., 2017. Zinc in Infection and Inflammation.Nutrients 9: 624-49.

GHANEM, M.M., EL-FKHRANY, S.F. , ABD ELRAOF, Y.M. , EL-ATTAR, H.M.,2012. Clinical and haematobiochemical evaluation of diarrheic neonatal buffalo calves with reference to antioxidant changes.Benha Veterinary Medical Journal, Vol. 23, No. 2,: 275-288

GaNHEIM, C., ALENIUS, S., AND WALleR, K.P., 2007. Acute-phase proteins as indicators of calf herd health. Vet. J. 173: 645-651.

GULTEKIN, M., VOYVODA, H., URAL, K., ERDOGAN, H., BALIKCI, C., AND GULTEKIN, G., 2019. Plasma citrulline, arginine, nitric oxide, and blood ammonia levels in neonatal calves with acute diarrhea. J. Vet. Intern. Med. 33:987-998.

GUZELBEKTES, H., COSKUN, A., AND SEN, I., 2007. Relationship between the degree of dehydration and the balance of acid-base changes in dehydrated calves with diarrhea. Bull Vet. Inst. Pulawy, 51: 83-87.

HAJIMOHAMMADI, A., NAZIFI, S., ANSARI-LARI, M., KHOSHMANZAR, M., AND BIGDELI, S., 2013. Identifying relationships among acute phase proteins (haptoglobin, serum amyloid A, fibrinogen, ceruloplasmin) and clinical findings in dairy calf diarrhea. Comp. Clinic. Pathol., 22: 227-232.

KABU, M., AND ALBAYRAK, H., 2016. Determining Serum Haptoglobin and Cytokine Concentrations in Diarrheic Calves .F.Ü. Sağ. Bil. Vet. Derg.; 30 (2): $113-117$

KAPER, J.B., NATARO, J.P., MOBLEY, H.L., 2004. Pathogenic E coli. Nat Rev Mic; 2:123-40.

KIRKAN, S., PARIN, U., ASCI, I. B., AND YUKSEL, H. T., 2018. Investigation of Enterotoxigenic Escherichia Coli Species Which Take Role in Calf Diarrhea and Detection of their Antimicrobial Susceptibility. Appro. Poult. Dairy \& Vet, Sci. 5(1).

KLEIN, D., ALISPAHIC, M., SOFKA, D., IWERSEN, M., DRILLICH, M., AND HILBERT, F., 2012. Prevalence and risk factors for shedding of thermophilic campylobacter in calves with and 
without diarrhea in Austrian dairy herds' .J. Dairy Sci.96:1203-1210.

KOJOURI, G. A., HASSANPOUR, H., TAGHAVI, N., AND TAGHADOSI, C., 2012. Nitric oxide metabolites status in calves with acute and chronic diarrhea. Comp. Clin. Pathol. 21:1257-1261.

KONEMAN, E.W., ALLEN, S.D., DOWELL, V.R., JANDA, W.H., AND SOMMERS, H.M.,1992. Color Atlas and Textbook of Diagnostic Microbiology. $4^{\text {th }}$ Ed. J.B. Lippincott CO., New York.

LUIKING, Y.C., POEZE, M., RAMSAY, G., AND DEUTZ, N.E., 2005. The role of arginine in infection and sepsis. J Parenter Enteral Nutr. 29:70-74.

MOHAMMED, S.A., MAROUF, S. A., ERFAN, A. M., EL-JAKEE, J.A.A., HESSAIN, A.M., DAWOUD, T.M., KABLI, S.A., AND MOUSSA, I.M., 2019. Risk factors associated with E. coli causing neonatal calf diarrhea. Saudi J. of Biological Sciences 26, 5: 1084-1088

MORIFNIGO, M.A., BORREGO, J., AND JANDROMERO, P., 1986.Comparative study of different method for detection and enumeration of Salmonella spp. In natural waters Appl. Bacteriol. 61: 169-176.

MUKTAR, Y., MAMO, G., TESFAYE, B., AND BELINA, D., 2015.A review on major bacterial causes of calf diarrhea and its diagnostic method. J. Vet. Med. Anim. Health 7:173-185.

MURRAY, C.F., WINDEYER, M.C., DUFFIELD, T.F., HALEY, D.B., PEARL, D.L., WAALDERBOS, K.M., AND LESLIE, K.E.,2014.Associations of serum haptoglobin in newborn dairy calves with health, growth, and mortality up to 4 months of age. $\mathbf{J}$ Dairy Sci. Dec; 97(12):7844-55.

NCCLS (NATIONAL COMMITTEE FOR CLINICAL LABORATORY STANDARDS) 2002. Performance and dilution susceptibility test for bacteria isolates from animals"Approved Standers" $2^{\text {nd }} \mathrm{Ed}$. M3t Az . NCCL. Wayne Pennsylvania ,USA.

NIAZE, B., KHAN, A., JAVED, M.T., HUSSAIN, A., AND AHMAD, K.M.,2000. Haematological studies in induced Buffalo neonatal calf diarrhea with Enteropathogenic E coli. Pakistan Vet J 20(2): 85-89.

NUNN, C.L., 1993. Effect of vitamin $E$ and selenium on neonatal immunoglobulin levels and incidence of scours in beef calves. Ore. Ag. Exp. Sta. Tech Paper No. 10,726 .

PEETERS, L., AND VANTRAPEN, R., 1977.Factors influencing lysozyme determination by lysoplate method. Clin. Chim. Acta., 74: 217-255.

PETERSEN, H.H., NIELSEN, J.P., AND HEEGARD, P.M.H., 2004.Application of acute-phase proteins in veterinary clinical chemistry. Vet. Res., 35: 163-187.

POURJAFAR, M., BADIEI, K., NAZIFI, S., AND NAGHIB, S.M., 2011. Acute phase response in Holstein dairy calves affected with diarrhea. Bulg. J. Vet. Med., 14: 142-149.

QUINN, P.J., CARTER, M.E., MARKEY, B.K., AND CARTER, G.R., (2013). Clinical Veterinary Microbiology $2^{\text {nd }}$ edition.Mosby. St Louis, United States.

RACHMILEWITZ, D., STAMLER, J.S., BACHWICH, D., KARMELI, F., ACKERMAN, Z., AND
PODOLSKY, D.K., 1995.Enhanced colonic nitric oxide generation and nitric oxide synthase activity in ulcerative colitis and Crohn's disease. Gut; 36:71823.

RAMADAN, M. Y., KHATER, H. F., ABD EL HAY, A.R., and ABO ZEKRY, A., 2015. Studies on parasites that cause diarrhea in calves. Banha veterinary medical journal, VOL. 29, NO. 1:214-219.

SEIFI, H. A., MOHRI, M., SHOOREI, E., AND FRZANEH, N., 2006.Using haematological and serum biochemical findings as prognostic indicators in calf diarrhea. Comp.Clin. Pathol. , 15: 143-147.

SMITH, D.R., 2012. Field disease diagnostic investigation of neonatal calf diarrhea. Vet Clin North Am Food Anim. Pract. 28:465-481.

SMITH G.W., 2009. Treatment of calf diarrhea: oral fluid therapy. Vet Clin North Am Food Anim.; 25:55-72.

SOWMYANARAYANAN，T.V., NATARAJAN，S.K., RAMACHANDRAN, A., SARKAR, R., MOSES, P.D., SIMON, A., AGARWAL, I., CHRISTOPHER, S., AND KANG, G., 2009.Nitric oxide production in acute gastroenteritis in Indian children. Trans R Soc Trop Med Hyg.; 103:849-851.

TEW, J.G., SCOTT, R.L., AND DONALDSON, D.M., 1971. Plasma $\beta$-Lysin and Lysozyme Following Endotoxin Administration and the Generalized Shwartzman Reaction.Experimental Biology and Medicine, Volume: 136 issue: 2: 473-478.

TRIPATHI, P.,TRIPATHI, P., KASHYAP, L., AND SINGH, V.,2007. The role of nitric oxide in inflammatory reactions. FEMS Immunol Med Microbiol. 51(3):443-52.

WEAVER, D.M., TYLER, J.W., VANMETRE, D.C., HOSTETLER, D.E., AND BARRINGTON, GM., 2000. Passive transfer of Colostral immunoglobulin's in calves. J Vet Intern Med; 14:569-577.

WHO. 1977. Expert committee on biological standardization. Technical report series 610 .WHO. Geneva .

YANG, X., SUN, Q., ASIM, M.B. R., JIANG, X., ZHONG, B. SHAHZAD, M., ZHANG, F., HAN, Y., AND LU, S., 2010. Nitric oxide in both bronchoalveolar lavage and serum is associated with severity of antigen-induced pulmonary inflammation in rats. Journal of Asthma, 47:135-14.

How to cite this article:

Ashgan F. El-Sissi; Abeer, S.Hafez and Atia, A. ElGedawy.2020. Evaluation Of Immunological Status Of Calves Suffered From Diarrhea Under Field Condition. Journal of Applied Veterinary Sciences, 5(2): 40-48. DOI: $\underline{\text { HTTPS://DX.DOI.ORG/10.21608/JAVS.2020.85580 }}$ 
Ashgan F. El-Sissi et al...... 